\title{
The Decline of the Traditional Orientalism in Don Delillo's Falling Man
}

\author{
Saad Abd Saadoon ${ }^{1}$, Dr. Wan Mazlini Othman ${ }^{2}$
}

${ }^{1} \mathrm{Ph}$. D. Student in Literature, Faculty of Languages and Communication, University Pendidikan Sultan Idris, Kula Lumpur, Malaysia ${ }^{2}$ Dr, Faculty of Languages and Communication, University Pendidikan Sultan Idris, Tg. Malim Perak, Malaysia

\begin{abstract}
This article attempts to explore neo-orientalism in Don Delillo's Falling Man. The study will mainly focus on islamophobia as the essential impetus of neo-orientalism. Postcolonial critical stances emphasize the issue of orientalism as the opposite of the West. Western civilizations used to perceive the traditional orient in the light of "self" and "other" dichotomy, whereby the West is the self that spreads its hegemony on the Orient, or East i.e., the other. Traditional orientalism is, therefore, based on this long inherited ideological assumption. However, this study focuses on neo-orientalism as a binary opposition of the Western hegemony. Some extreme Islamic attitudes reject American Western hegemony. Accordingly, they express their ideological will through relying on some religious ideas to attack America. Such response results in islamophobia midst Western societies. In so doing, they justify their rebuttal of the Western hegemony in order to establish their own oriental identity. The study is going to discuss this rebuttal as a way of empowering traditional orientalism which turns to be neo-orientalism. For this reason, it will apply three postcolonial concepts, namely, hegemony, self-other relationship and islamophobia. Thus, the application of these concepts will reveal the formation of neo-orientalism as a means of elevating oriental traditional identity.
\end{abstract}

Keywords - Hegemony, Identity, Islamophobia, Orientalism, Self-Other Relationship.

\section{INTRODUCTION}

Islamophobia is an avant-garde cultural concept. It came into prominence since the last decades of the twentieth century. Yet, it became more evident in the cultural and political discourse since the beginning of the twenty-first century, especially after the $11 / 9$ September 2001 . In the main, the issue of islamophobia has become of paramount importance in all socio-cultural fields because it represents a holistic complex issue in the context of human affairs in all over the world. As such, the comprehensive peculiarities of islamophobia and its pertinent consequences brought about modern and up-to-date notions concerning the position of Muslims in the world in general; and the United States of America in particular. Being so, the position of Muslims in the United States of America is the most conspicuous feature of islamophobia as a concept (Saeed, 2016).

There are several relevant affairs that came along with the palpable appearance of islamophobia;chief among them are terrorism, fanaticism and strict religious attitudes that exemplify the very notion of islamophobia within the broad sense of politics. Consequently, a new phrase was coined in relation to the attacks that took place in 2001 and their extreme impact on the world view of Islam. This phrase is "war against terrorism" which was first used by President G.W. Bush in his emergent discourse shortly after the attacks. Therefore, there have been serious and somber attempts to obliterate the roots of terrorism (Bakali,2016).

The United States of America, in this context, has been leading military massive campaigns to locate the source of terror in order to put an end to it. In a striking way, the concept of islamophobia began to rise as long as there is any plan to eradicate the Islamic attempts to create distracting actions, like the 2001 attacks. For this reason, the necessity for finding proper outlets, which decrease the threat of islamophobia, has become more vital than ever. Islamophobia, accordingly, began to take a universal sense as it touches the most significant national affairs in the world (Meer, 2016).

The relationship between islamophobia and the world countries corresponds to the fact that Islamic extreme terrorists might threaten the national security of any country at any time. As such, world nations set emergent regulations for any abrupt attacks which might be led by Islamic extreme persons (Dawoody, 2016). Here, the Islamic extremism has 
sustained another relevant concept i.e., fanaticism. Like extremism, fanaticism embodies the Islamic extreme attitudes towards the others, yet, it may be undertaken by individuals who oppose certain political decisions; while the extremists might ascribe the political decisions to the religious view as a faithful creed. Being so, both religious extremism and fanaticism creed relate to the concept of islamophobia (Soharwardy, 2016). This study tries to explore this new perception as "neo orientalism." In this regard, the study will discuss three pertinent topics in the course of the analysis, namely, identity and the violent attacks depicted in the novel's plot, hegemony and self-other relationship in Don Delillo's Falling Man. These topics will be elaborated to interpret the representation of Islamophobia as the main impetus of new orientalism depicted in the novel.

\section{IDENTITY AND SCENES OF VIOLENCE IN DELILLO'S FALLING MAN}

Delillo's Falling Man hinges on the terror experience of Keith Neudecker. He is a lawyer and works at the World Trade Centre. From the novel's onset, he seems to be a man in his late thirties of age. Keith seeks refuge in his flat in which he lives together with his Justin and wife Lianne. The reason behind his escape is the attacks that took place in 09/11/2001. He has been harmed during the attacks; and he deiced to leave the place for a safer building. He recovers from his injuries after long time. He seems to be both physically and psychically hurt by the attack. When he feels better, he becomes to lead a habitual life.

Again, he meets his wife Lianne. However, he encounters another woman named, Florence, and they develop amorous affectation towards each other. They previously met at the World Trade Centre. They survive the terrorist attacks. He unconsciously snatches Florence's briefcase as he got out of the collapsing building. Florence seems to be despondent since she is not satisfied with her living with her mother Nina and Martin; her delicate boyfriend. Later, Keith gets fed up with his life, and he decides to roam the world participating in his favorite game; poker contests. While he wanders the world, he keeps recalling dead people who lost their lives in the notorious attacks. The novel ends with his whimsical behaviors.

The violent scenes appear from the very beginning of Delillo's Falling Man. The omniscient narrator narrates the story of the attacks. He is completely overwhelmed by horror scenes on the day of the attack. In the course of the violent events, he describes the radical devastation of the attack upon the streets and the other places. Then, the scene sheds light on Bill Lawton; the protagonist of the novel: "It was not a street anymore but a world, a time and space of falling ash and near night. He was walking north through rubble and mud and there were people running past holding towels to their faces or jackets over their heads. They had handkerchiefs pressed to their mouths" (p.15). Then, the narration scene concentrates on the feelings of people who had undergone such horrible experience: "They had shoes in their hands, a woman with a shoe in each hand, running past him. They ran and fell, some of them, confused and ungainly, with debris coming down around them, and there were people taking shelter under cars" (p.15). Here, Dellilo portrays the reaction of people, including the protagonist, to the violent attacks. These attacks influence both people and the regional surroundings.In a striking way, the protagonist, $\mathrm{s}$ name, Bill Lawton, is an anagram of Bin Laden, the Surname of Osama Bin Laden, the real leader of the attacks.

The violent scenes, in oriental literary discourses, emanate from the notions of resistance. Violent resistance involves both the oppressed and the oppressor. It takes different shapes during the political encounters between the suppressed people and their oppressive counterparts. In other words, resistance is a form of regainingdeformed identity; or as Abdalhadi Abu Jweid (2016) puts it simply, it reinforces the distorted identity (p.532). Violent resistance is considered as the most appropriate means of eliminating the west colonialism and its destructive agendas. This is due to violence that brings about negative influences upon the socio-cultural traditions of the oppressors. Consequently, the oppressed people tend to obliterate oppression in order to gain their cultural residuals before the advent of the west hegemony. The long oppression periods make the oppressed people feel that they need liberty and national progress in all life's aspects (Aulette, 2017). As such, they begin to find suitable exist for the oppression imposed over them. The resistance tools vary and differ from each other. In Delillo's Falling Man, the attackers exemplify the oppressed people who consider themselves as victims of the west. As a result, they begin to lead violent attacks against the oppressed in order to get rid of their oppression. Yet, the whole violent matter happens in the ideological encounter between the United States and the extreme pilot who hijacked the planes and hit the twin towers.

The plot's onset primarily focuses on the violent scenes. The attacks spread over the whole place. They include some terrifying sounds that create a sense of fright. The bombing devastated the normal shape of the place before the attack: "The roar was still in the air, the buckling rumble of the fall. 
This was the world now. Smoke and ash came rolling down streets and turning corners, busting around corners, seismic tides of smoke, with office paper flashing past, standard sheets with cutting edge, skimming, whipping past, otherworldly things in the morning pall" (p.15). This quotation conveys the extent to which the destruction could damage the place's features. Delillo, presumably, seems to be concerned with violence and its ability to demolish the civilization aspects, such as the towers and people's peaceful life.

One of the most conspicuous means of resisting violence is rebellion. It enables the oppressed people to get rid of suppression. Resisting oppression comes in the form of rebellion when the exploited minorities need to be independent. They try to seek self-autonomy since they long for equality and liberty. The cultural discrimination, therefore, arises based on religion and ethnicity which hinders the oppressors from obtaining their peace. Consequently, the suppressed people begin to plot against their oppressors by planning authentic tactics to achieve their independence goals. The process of plotting against the colonizers is often argued as "conspiracy"; whereby the colonized people reach their aims by rejecting oppression through violent resistance (Aulette, 2017, p.18). In Delillo's Falling Man, similarly, the attackers conspire against the United States by making public turmoil. They could upset the public security through the attacks that left their apparent impact upon the American foreign politics for many years. The attackers, in this way, represent the oppressed minority that tries to uproot their oppressors.

Delillo's Falling Man precisely parades the huge turmoil caused by the attacks. It highlights the influence of the accident on the protagonist's situation. The fictional events simulate the actual action that happened in the morning of the attacks. Delillo uses his fictional protagonist, Bill Lawton, as an incarnation of the American individuality. That is, he embodies the mass American people who are affected by the sequences of the violent attacks. In so doing, Delillo utilizes the protagonist in a symbolic mode. He gets in agitated rush soon after the event: "He wore a suit and carried a briefcase. There was glass in his hair and face, marbled bolls of blood and light. He walked past a Breakfast Special sign and they went running by, city cops and security guards running, hands pressed down on gun butts to keep the weapons steady" (p.15). Delillo, furthermore, depicts the common turmoil left by the attack. The police get ready and prepare weapon in order to face any other similar attack. This attack is undertaken by persons that are thought to be enemies of the American public security. Their action justifies their reaction towards oppression imposed upon them by the American hegemony. In this sense, the violent actions are signs of reactionary responses to hegemonic oppression.Such fatal encounters are motivated by the feelings of superiority and inferiority; whereby the Americans believe that they are superior to the Muslims that seek to get rid of inferiority complex.

Extreme Muslims, therefore, resist the feeling of inferiority through violence. They practice their will by destructing the American belongings, such as the trade center towers in Delillo's Falling Man. The protagonist suffers from the harsh situation after the attack. He is distracted by the surrounding agitation caused by the hitting of the tower by the extremists' attacks: "Things inside were distant and still, where he was supposed to be. It happened everywhere around him, a car half buried in debris, windows smashed and noises coming out, radio voices scratching at the wreckage" (pp.15-16). He, them, sees harmed people around the twin towers' rubble: "He saw people shedding water as they ran, clothes and bodies drenched from sprinkler systems. There were shoes discarded in the street, handbags and laptops, a man seated on the sidewalk coughing up blood. Paper cups went bouncing oddly by" (p.15). This attack is the manifestation of the Muslims' attempt to get rid of the inferiority complex imposed on them by the hegemonic American ideology. Consequently, the attack is organized on the hatred relationship between the American oppressors and the extremists who think that they are oppressed by the Americans.

This tragic experience entails the concept of violence which refers to the suppressed minorities to regain their oppressed identity. It indicates the oppressed people's continual struggle to affirm their original identity that is destructed by the hegemony of the self, i.e. American. Accordingly, the concept of violence has a contiguous relationship with identity (Hodgkins, 2002, p.32). In the main, orientalism, as a critical approach, emphasizes the idea of original identity both before and after oppression that comes out of the encounters between the "self" and "other" (p.33). The conceptualization of identity before oppression exemplifies the original people's struggle to maintain their inherited customs and traditions.

In Delillo's Falling Man, the basic encounter takes place between violent attackers as "other" that try to exterminate the Americans that are described as "self" in the course of the plot. Delillo's omniscient narrator meticulously describes this oppositional encounter by narrating the Americans' response 
to the attacks: "The world was this as well, figures in windows a thousand feet up, dropping into free space, and the stink of fuel fire, and the steady rip of sirens in the air. The noise lay everywhere they ran, stratified sound collecting around them, and he walked away from it and into it at the same time" (p.16). In this situation, the Americans seem to be moved by the violent attack. It disturbed their lives; and it hinders their national security. The event incarnates the oppositional ideological points of view between the United States of America and the extreme attackers. These violent extremists, in fact, seek to regain their devastated identity at the hands of the American oppressors.

Identity, therefore, undergoes radical transformation by the practices of the oppressors. The concept of violence, in this manner, sustains the oppressed minorities to think of regaining their deformed identity. They resort to violent resistance as a suitable means of rejecting oppression. Yet, as I have argued earlier, violent resistance has several shapes. It could be rebellion. But this rebellion requires bloody scenes, like plane hijacking or direct clash between the "self" and "other." Here, the oppressed people are not able to face their oppressors since they do not have that power to obliterate the oppressors' hegemonic dominance (Branche, 2015). For this reason, they resort to fatal action without using weapons, such as hijacking, bombing, hitting buildings and the like (Hodgkins, 2002). In Delillo's Falling Man, the extreme attackers try to regain their identity through such fatal practices.

The extremists represent the struggle for identity. On the other hand, the American society exemplifies the obstacle that hinders the extremists to reinforce their identity. Delillo conveys this cultural discrepancy through the protagonist who is one of the victims that witnessed the violent attacks. The narrative structure of the novel shifts between the position of the protagonist in the violent accident and the sequences of the attack in the same place: "There was something else then, outside all this, not belonging to this, aloft. He watched it coming down. A shirt came down out of the high smoke, a shirt lifted and drifting in the scant light and then falling again, down toward the river" (p.16).

\section{HEGEMONY AND SELF-OTHER RELATIONSHIP}

The concept of Self-Other relationship comes into prominence with the publication of Edward Said's seminal book Orientalism. By arguing this relationship, Said (1979) introduces "the vacillation between the familiar and the alien" (p.72). Additionally, he invokes "familiar" and "alien" as the relationship between "Self" and "Other." Any confrontation between two opposite colonial groups could result in a contradictory relationship between these groups. This relationship results in the "validity of the division of races into advanced and backward" colonial society (p.206). This relationship also "has a mission to enlighten, civilize, bring order and democracy, and that it uses force only as a last resort. And, sadder still, there always is a chorus of willing intellectuals to say calming words about benign or altruistic empires" (p.25). Self-Other relationship comes out "as if one shouldn't trust the evidence of one's eyes watching the destruction and the misery and death brought by the latest mission civilizatrice" (p.26). In this regard, Self-Other relationship portrays the Islamic extremists as the "other" who is suppressed by the American foreign policy; such policy is considered as the "Self."

In Delillo's Falling Man, the Self-Other relationship is primarily between the extremists and the American politics. The result of this ideological confrontation is that the extremists devastated the habitual faced of the American everyday life. This is true to the protagonist's position in the city after the attack. The city seems to be ghost-like due to the lack of means of transportation: "He tried to tell himself he was alive but the idea was too obscure to take hold. There were no taxis and little traffic of any kind and then an old panel truck appeared, Electrical Contractor, Long Island City, and it pulled alongside and the driver leaned toward the window on the passenger's side and examined what he saw, a man scaled in ash, in pulverized matter, and asked him where he wanted to go" (p.18). The protagonist's agony intensifies as he spends time in the damaged city: "It wasn't until he got in the truck and shut the door that he understood where he'd been going all along" (p.18).

In this regard, Said (1979) contends that the Self-Other relationship is a kind of imperial exploitation. Such kind of imperial exploitation is set within the limits of self-other relationship because "colonial discourse analysis theory is its dependence on the discursive coherence of colonial relations; through which the Self/Other relation is introduced as fixed binaries. The construction of the colonial subject is depicted through a discursive essentialist mode of representation whose basic features are stability, autonomy and coherence" (Ahmad, 1992,p.62). This coherence is "the split between the two primary entities" (27). In Delillo's Falling Man, the "two primary entities" are the Islamic extremists and their American counterparts. The core sense of these entities lies in the discrepant relations among them. Each entity perceives and judges the other entity in the light of ideological 
disagreement. They try to demolish each other in a long rally for ideological superiority. The protagonist undergoes horrible experience that comes out of this ideological struggle: "He heard the sound of the second fall, or felt it in the trembling air, the north tower coming down, a soft awe of voices in the distance. That was him coming down, the north tower" (p.17). In this scene, the protagonist is shocked by the horrible incidents done by the extremists. In fact, he exemplifies the victims of the imperial clash between the attackers and the American political representatives that denote the essence of the imperial Self-Other relationship.

The relationship between the extremist and the American imperial politics is based on the proems of dual entities i.e. Self-Other relationship. These entities have "become part of the common colonial suppressive discourse, the very similar colonial discourse" (Sheffer, 1986,p.46). This suppressive dimension "produces a narrative that reacts conversely to the colonial monolithic discourse of power relations. The whites exhibit a marvelous capacity to be inside and outside the colonial culture dominant in these discourses; they could transcend the deeply troubling and essentialized self/other approach to colonial relations that often entrap it" (Williams, 2015,p.73). The colonial discourse is conveyed through the horrible attacks depicted in Delillo's Falling Man. The novel's narrator pinpoints the attacks in order to give a panoramic impression of how the effect of the attack was. At this point, Delillo projects his own authorial insights in the course of the plot for the sake of portraying the attack in its ultimate negative influence: "In time he heard the sound of the second fall. He crossed Canal Street and began to see things, somehow, differently. Things did not seem charged in the usual ways, the cobbled street, the cast-iron buildings" (p.17).

Delillo puts forth this clash in terms of Self-Other relationship. This is because orientalism poetics has a resounding literary potential midst human and cultural disciplines. Orientalism advocates a common sense regarding the position of human in society. Yet, such position goes along with the way human's life corresponds to the current state of politics, sociology, anthropology and so forth. Man, hence, is depicted via an enigmatic literary manner. Man's inferiority, henceforth, is what distinguishes the stereotypical postcolonial discourse. This literary manner sets out "to signify the wide range of discourses, ideologies and intellectual formations which have emerged from cultures that experienced imperial encounters" (Newell, 2006,p.3). In like fashion, Delillo depicts this inferiority in Falling Man. He utilizes the real events of 9/11/2002 as fiction replica of how the extremists resort to violent attacks to justify their negative response to the U.S foreign policy. In the long run, their response makes them attack the towers as a way of repudiating that policy; the novel's narrator, again, comments on the sequences of this attack: "There was something critically missing from the things around him. They were unfinished, whatever that means. They were unseen, whatever that means, shop windows, loading platforms, paintsprayed walls. Maybe this is what things look like when there is no one here to see them" (p.17). To use Said's (1979) arguments, the attackers' response towards the American policy is the embodiment the Self-Other relationship between the Orient and the Occident on the grounds of cultural impetuses.

The cultural encounter is another definitive feature of oriental-related literature. Different cultures or ideologies conflict among each other in order to pose power by which each front tries to affirm its hegemonic position. Being that so, oriental literature provides a bustling vitality in accordance with the dominating power at the ultimate sense of this encounter. The powerful position, then, could construct its ideology and exerts its cultural insinuation via well-implemented procedures. Most significantly, the language of oriental discourse is the perennial tool used by writers to incarnate the scenario of these conflicting powers; whereby "a sufficiently thick knowledge of the cultural context of a work would ideally include the knowledge" of those powers "that put pressure" on the theme in "which the work is written" (Tabron, 2033,p.17).

In Delillo's Falling Man, the theme is essentially the relationship between America as a representation of the "Occident" and the extremists as the representation of the "Orient." At the heart of this relationship, there are contradictory and violent points of view regarding each ideological pattern. Said tends to describe this relationship as Self-Other because each pattern has its own conceptualization and perception of the other. The protagonist, in Falling Man, incarnates the observer of this relationship since he survives the attacks; and he undergoes its tragic experience: "Three police vans came veering into the street and sped downtown, sirens sounding. He closed his eyes and drank, feeling the water pass into his body taking dust and soot down with it" (p.17).

Self-Other relationship, says Said (1979), is governed by cultural and hegemonic powers (p.62). Being so, the language of oriental discourse aligns to the way by which hegemonic powers strive to impose certain cultural practices upon the other cultural entities i.e., some hegemonic powers 
have an encompassing schedule to subjugate the suppressed entities in order to spread their hegemonic inherent culture (Chew, 2014, p.1). Accordingly, the overall postcolonial state of being manages to "offer both a critique of theories of the performative and detailed readings of literary texts, particularly in terms of a poetics of the real, in order to explore how we may move beyond the difficulties" (Rooney,2007,p.1).

Here, the violent competition, in Falling Man, is initiated by the extremists as a way of expressing the rejection of the U.S hegemony, or as Said puts it simply, the "Other" competes and negates the "Self." Therefore, the extremists utilize violence to rebuff the hegemony of the American imperial ideology. The novel parades a scene of the attack when people are frightened by striking the towers: "He saw members of the tai chi group from the park nearby, standing with hands extended at roughly chest level, elbows bent, as if all of this, themselves included, might be placed in a state of abeyance" (p.16). In the course of the introductory scenes, the novel intensively describes the direct clash between the "Self" and "Other." The clash represents the attackers' will to put an end to the hegemonic practices of the American foreign policy against the Islamic extremists. To put it in other words, the American hegemony is severely confronted by the "Other's" aspiration to get autonomy from it.

In Delillo's Falling Man, the U.S ideology is attacked by the extremists who feel that they are suppressed by that ideology. They begin to respond to the American ideology via violent reactions in order to affirm their own beliefs. Consequently, they left profound sense of agony in the lives of the attacks of the survivors; the novel's narrator recounts his own health ordeal and other people's agony after the attack: "Someone took the glass out of his face. The man talked throughout, using an instrument he called a pickup to extract small fragments of glass that were not deeply embedded. He said that most of the worst cases were in hospitals downtown or at the trauma center on a pier. He said that survivors were not appearing in the numbers expected. He was propelled by events and could not stop talking" (p.29). The narrator also describes the doctors who participated in human services to the live s of the survivors: "Doctors and volunteers were standing idle, he said, because the people they were waiting for were mostly back there, in the ruins. He said he would use a clamp for deeper fragments" (pp.29-30). In this context, the attacks' sequences typify the extremists' responsive attitudes towards the U.S. hegemonic policy that marginalizes their life and their position in the world. They oppose the American hegemony in all its aspects because
Self-Other relationship has ideological "power relations" (Edmond and Smith, 2003,p.1).

The ideological trajectory of the "Self" and the "Other," in Delillo's Falling Man, originates in the extremists' attempt to destruct the global hegemony of the U.S. The attack elucidates the extremists' serious response to reject the hegemonic power of the American foreign policy. Delillo carries out this relationship through the influence of the lives of the common people who are directly harmed by the attack. In essence, the attack represents the threat of the extremists to belittle the ability of the American representatives to offer proper public security for citizens; the following quotation dispatches the vexing experience of the attacks: "In those places where it happens, the survivors, the people nearby who are injured, sometimes, months later, they develop bumps, for lack of a better term, and it turns out this is caused by small fragments, tiny fragments of the suicide bomber's body" (p.30). The novel's narrator further describes the attacks harsh influence upon the victims' lives: "The bomber is blown to bits, literally bits and pieces, and fragments of flesh and bone come flying outward with such force and velocity that they get wedged, they get trapped in the body of anyone who's in striking range" (p.30). The attack epitomizes the contradictory ideology between the "Self" and "Other" that perceive and judge each other on hegemonic grounds. In fact, the attack brought about new conceptual perceptions regarding the Islamic extremists. In so doing, they spread the notion of islamophobia. The following section, therefore, will discuss the representation of islamophobia in Delillo's Falling Man and how it leads to the sense of new orientalism.

\section{ISLAMOPHOBIA AND NEO ORIENTALISM}

Islamophobia is a new concept that came into light approximately in the 1990s. Yet, it is more concomitant of the 09/11 attacks in 2001. Several scholars tired their hands to identify the specific peculiarities of the concepts since then. Chris Allen (2010), in Islamophobia, argues that the concept of "Islamophobia has gained a far greater prevalence across both the public and political spaces. In the most vocal instances, claim and counter claim to Islamophobia typically emerges from bi-polar extremes, from those who decry and denounce any criticism whatsoever of Muslims or Islam as being 'Islamophobia' to those who actively and openly espouse a vitriolic hatred" (p.3). In this respect hatred is a contiguous term that is used alongside the concept of islamophobia. But the depiction of islamophobia is 
conducted through the western depiction of Islam in literary works.

In Delillo's Falling Man, the image of Islam is introduced to the west by the poetry of Shelley. The poetry conveys the military aspects of Islam: "In It was the postcard that snapped her back, on top of the cluster of bills and other mail. She glanced at the message, a standard scrawled greeting, sent by a friend staying in Rome, then looked again at the face of the card. It was a reproduction of the cover of Shelley's poem in twelve cantos, first edition, called Revolt of Islam" (p.21). The postcard exemplifies the sense of Islam as a religion of military politics. And the military aspects are conveyed through the depiction of the revolt of Islam:"Even in postcard format, it was clear that the cover was beautifully designed, with a large illustrated $R$ that included creatural flourishes, a ram's head and what may have been a fanciful fish with a tusk and a trunk. Revolt of Islam" (p.21).

Delillo carries out this notion through allusion. He alludes to the poetry of Shelley: "The card was from the Keats-Shelley House in Piazza di Spagna and she'd understood in the first taut seconds that the card had been sent a week or two earlier. It was a matter of simple coincidence, or not so simple, that a card might arrive at this particular time bearing the title of that specific book" (p.21). The image of Islam, to use Said's words, corresponds to the image of Islam as "Orient" and the West, including the U.S.A, as the "Occident." Yet, the depiction of Islam in Delillo's Falling Man differs from the traditional appropriation of the concept. Therefore, I tend to describe it as new orientalism.

Delillo, in Falling Man, portrays the cautious behaviors of Muslims in the American society after the extreme attacks. Elena, for example, behaves cautiously when she interacts with other people: "A woman named Elena lived in that apartment. Maybe Elena was Greek, she thought. But the music wasn't Greek. She was hearing another set of traditions, Middle Eastern, North African, Bedouin songs perhaps or Sufi dances, music located in Islamic tradition, and she thought of knocking on the door and saying something" (p.89). Here, Elena represents the "oriental" tradition because she comes from Middle Eastern background, while her social peripheries are the "Occident" because they deal with her as a foreigner. As a rule of thumb, the relationship between the "Orient" and the "Occident" cultural backgrounds emanate from the self-other relationship (Said, 1979, p.94).

In Delillo's Falling Man, similarly, the discrimination views against Muslims are conspicuous. Elena and other characters, like Hammad, suffer from racial discrimination after the attacks. He is not satisfied with the common socio-cultural traditions of the west. He thinks that the west, exemplified in the U.S.A, tries to demolish the ideals of Islam: "Hammad sat crouched, eating and listening. The talk was fire and light, the emotion contagious. They were in this country to pursue technical educations but in these rooms they spoke about the struggle. Everything here was twisted, hypocrite, the West corrupt of mind and body, determined to shiver Islam down to bread crumbs for birds" (p.101). At this point, the clash between the American corruption and Islam's ideals are signs of islamophobia in the form of racial discrimination against extreme Muslims.

Furthermore, Muslims, like Hammad are partially restricted form. They strictly deal with other people on the same social milieus. A man talks with Hammad about these discriminatory issues: "The man who led discussions, this was Amir and he was intense, a small thin wiry man who spoke to Hammad in his face. He was very genius, others said, and he told them that a man can stay forever in a room, doing blueprints, eating and sleeping, even praying, even plotting, but at a certain point he has to get out" (p.102). The man embodies the American islamophobia attitudes towards Muslims. He tells Hammad how the Islamic teachings instruct Muslims to deal with non-Muslims: "Even if the room is a place of prayer, he can't stay there all his life. Islam is the world outside the prayer room as well as the sürahs in the Koran. Islam is the struggle against the enemy, near enemy and far, Jews first, for all things unjust and hateful, and then the Americans" (p.102). In this quotation, the struggle against the Americans is the essence of islamophobia. The man delivers his islamophobia views concerning Islam and its view of America. To refer to Said's (1979) arguments, Hammad stands for the "oriental" Islam that opposes the "occidental" American ideology. Hatred lies at the heart of this self-other relationship; and it creates the sense of islamophobia.

Delillo depicts this attitude in Falling Man. He describes how Islam is put under attack in the U.S.A because of its religious ideologies. Again, this attack is conducted after the 09/11/2001 attack. In the novel, some men go down the street. They are afraid of the security inspection, but they are not inspected in the course of the situation. Yet, they know well that Islam is being severely inspected in the U.S.A due to the spread of islamophobia: "The men went to Internet cafés and learned about flight schools in the United States. Nobody knocked down their door in the middle of the night and nobody stopped them in the street to turn their pockets inside out and grope their bodies for weapons. But they knew 
that Islam was under attack" (p.105). This islamophobia situation denotes the radical spread of Islam as a religion of terror. Therefore, people used to be afraid of this religion and its threat upon their lives. The American official, accordingly, imposes strict inspection procedures on Muslim citizens.

The same islamophobia attitude is purported in Beate Winkler's Muslims in the European Union: Discrimination and Islamophobia. She (2006) argues that the concept of "islamophobia is a much used but little understood term...." and it refers to "policy and action to combat it is undertaken within the broad concepts of racism and racial discrimination, which are universally accepted by Governments and international organizations" (p.13). In the main, Winkler (2006) argues that the concept of islamophobia created a cultural discrimination against Muslims and their religious ideology: "Discrimination against Muslims can be attributed to Islamophobia attitudes, as much as to racist and xenophobic resentment, as these elements are in many cases inextricably intertwined" (p.19). Xenophobic feelings stimuli Muslims to commit suicidal operations in order to get rid of the oppressive hegemony because "racism, xenophobia and Islamophobia become mutually reinforcing phenomena and hostility against Muslims should also be seen in the context of a more general climate of hostility towards migrants and minorities" (p.19).

In Delillo's Falling Man, Hammad represents the "migrants and minorities" that suffer from the oppressive islamophobia. As a result, he begins to think of committing suicidal operation to enter the paradise and to be closer to God. As a matter of fact, his thoughts are stimulated by extreme Islamic teachings; and not the true ones. He prepares himself to bomb other people to achieve his will; the quotation below reflects his hostile attitude:

The weight loss had come in Afghanistan, in a training camp, where Hammad had begun to understand that death is stronger than life. This is where the landscape consumed him, waterfalls frozen in space, a sky that never ended. It was all Islam, the rivers and streams. Pick up a stone and hold it in your fist, this is Islam. God's name on every tongue throughout the countryside. There was no feeling like this ever in his life. He wore a bomb vest and knew he was a man now, finally, ready to close the distance to God. (p.209)

Hammad's action incarnates his rejection of the American prejudice. However, his suicidal action fortifies the sense of isislamophobia. Winkler (2006), in the same manner, contends that the concept of islamophobia is "the fear of or prejudiced viewpoint towards Islam, Muslims and matters pertaining to them. Whether it takes the shape of daily forms of racism and discrimination or more violent forms, Islamophobia is a violation of human rights and a threat to social cohesion" (p.61). Hammad, therefore, repudiates such discrimination through a violent reaction. He does not accept the ideological bias against him; and he resorts to a way of rebuffing discrimination at whatever cost. Just so, he commits suicide because he influenced by the extreme Islamic teachings that motivated the extremists to hit the twin towers. Notwithstanding, he does not recognize the effect of his suicide since it might increase the feeling of islamophobia midst the American society.

In Islamophobia and Its Consequences on Young People, Ingrid Ramberg (2004) also tries to define the concept of islamophobia. She says that the concept of "islamophobia can be defined as the fear of or prejudiced viewpoint towards Islam, Muslims and matters pertaining to them.... [and they are] experiencing an increasingly hostile environment towards them characterized by suspicion, deep-rooted prejudice, ignorance, and, in some cases, physical and verbal harassment" (p.6).Muslims, similarly, are treated in terms of hostility based on suspicion in Delillo's Falling Man. This is because Muslims have some religious concepts regarding the "Self." they describe the blasphemous and debauched people with word "Kufr." And these people should be opposed by a "jihad" which is also another word used to explain the sense of resisting blasphemy and debauchery. The novel presents some scenes that are close to these religious words: "they passed through, one or two, now and then, and sometimes they told him about women they'd paid for sex, okay, but he didn't want to listen.... Here they were in the midst of unbelief, in the bloodstream of the kufr. .... There was the claim of being chosen, out there, in the wind and sky of Islam. There was the statement that death made, the strongest claim of all, the highest jihad" (p.211). These unbelievers should be revisited via jihad since they undergo Kufr life. However, this resistance sustains hostility against Muslims. Consequently, it leads to "islamophobia" or hatred (Ramberg, 2004,p.84).

Andrew Shryock (2010)approaches the critical insights of the concept of islamophobia. He (2010) claims that "the term 'Islamophobia' could reasonably be applied to any setting in which people hate Muslims, or fear Islam" (p.2). The relationship between islamophobia and Muslim extremists is evident in Delillo's Falling Man. This is because 
islamophobia spreads after the Muslim extremist attack of the towers portrayed at the beginning of the novel. Hammad personality demonstrates Muslim extreme plans to attack the U.S.A. he urges other men to enlist in the jihad operations to attack the American society. If they do so, they will enter the promised paradise: "They looked at videos of jihad in other countries and Hammad told them about the boy soldiers running in the mud, the mine jumpers, wearing keys to paradise around their necks. They stared him down, they talked him down. That was a long time ago and those were only boys, they said, not worth the time it would take to be sorry for a single one" (p.103). Hammad, here, symbolizes the Muslim extremism archetype. In so doing, he spreads the sense of islamophobia.

Liz Fekete (2009) discusses the concept of islamophobia via xenophobia. She (2009) claims that "Islamophobia and xenophobia are woven into the war on terror" (p.99). In this way, the concept of islamophobia becomes a malady threatening the West. The relationship between the "Orient" and the "Occident," according to Fekete (2009), is based on hatred because islamophobia is an ideological disease that outbreaks in the "Occident's" geographical milieus. The stereotypical relationship between the "Orient" and the "Occident" is appropriated to the extremists' attacks and their unjustified horrible actions in Delillo's Falling Man. The narrator recounts Hammad's reactions towards the American ideological politics. He motivates some men to be prepared to attack the American society through suicidal attacks; the following quotation reflects his extremist thoughts

This entire life, this world of lawns to water and hardware stacked on endless shelves, was total, forever, illusion. In the camp on the windy plain they were shaped into men. They fired weapons and set off explosives. They received instruction in the highest jihad, which is to make blood flow, their blood and that of others. People water lawns and eat fast food. Hammad ordered takeout at times, undeniably. Every day, five times, he prayed, sometimes less, sometimes not at all. He watched TV in a bar near the flight school and liked to imagine himself appearing on the screen, a videotaped figure walking through the gate-like detector on his way to the plane. (p.210)

Hammad's terrorist attacks, in the light of Fekete's (2009) argument, are disease that breakout in the American society. His plans typify the Islamic extreme points of view concerning the American society. Thereupon, his religious ideology stands for the barbaric "Other" perceived by the American "Self." The core conceptual implication of islamophobia, in this context, is that Hammad is the extreme Islamic attribute. His personality illuminates the disposition of extreme Islamic ideology to a great extent. Yet, he does not comply with the fair and just ideals of Islam. His actions are mere ideological response against the American hegemony, or as Said (1979) puts is simply, he is the representative symbol of the rejection of hegemony constructed by self-other relationship (p.98). In the long run, the novel, presumably, prefigures new orientalism in terms of islamophobia. In contrast, such new orientalism entails the sense of moderate Islam depicted at the end of the novel:

People were reading the Koran. She knew of three people doing this. She'd talked to two and knew of another. They'd bought English language editions of the Koran and were trying earnestly to learn something, find something that might help them think more deeply into the question of Islam. She didn't know whether they were persisting in the effort. She could imagine herself doing this, the determined action that floats into empty gesture. But maybe they were persisting. They were serious people perhaps. She knew two of them but not well. One, a doctor, recited the first line of the Koran in his office.

This Book is not to be doubted (p.278).

This quotation refers to an outlandish and multifarious perception of Islam. The significance of this narrative point of view is that the west, or the American society, begins to appreciate the religious attributes of Islam in different ways. The Americans develop whimsical hostility feelings towards Muslims when they are affected by the notion of islamophobia. People gradually get curious about the primary origins of Islam and its related issues. Islam, as a monolithic religion provides its teachings in the form of revelation. Being so, it depends on revelation as the essential source of spiritual motivation. Delillo uses an erudite description of the fanatic Muslims who follow the Islamic teachings in a strict manner. They do not recognize its negative sequences on their lives in the west. They act atrociously by hitting the twin towers.

\section{CONCLUSION}

This article has focused on Dellilo's Falling Man is an exemplification of the issue of islamophobia. In the course of 
the novel, the ideological encounter between the attackers and the American individuality is a mere manifestation of the American hegemony exerted in a wide range of Islamic nations. In this way, the novel has a twofold symbolical literary mode. On the one hand, it depicts the encounter between Islamic extremists and the American political ideology and its will to impose its leadership in the Islamic world. The exact notions of the American leadership contradict with the Islamic aspiration to be independent. For this reason, the Islamic extremists led a sudden reaction against the American enterprise to counter-attack Islam. On the other hand, the novel carries out the reality of the ideological clash between the Americans and Islamic extremists.

The discussion of the islamophobia has comprised three pertinent issues. In a way or another, all the three issues interrelate because they come from the same oriental backgrounds. First, scenes of violence have been discussed in order to recapitulate the sense of fright and agitation created by the attacks. Such violence embodies Delillo's portrayal of the actual events that took place in 2001. However, Delillo uses literary narrations and some fictional episodes to accentuate the increase of islamophobia in the American society. He depicts the violence as the root of terrorism that had been the core conceptual appropriation of islamophobia. Being so, the novel carries within itself the rise of islamophobia in terms of the attacks narrated in the first paragraphs of the novel.

The depiction of the attacks at the beginning of the novel serves as a literary orientation of the sequences of the attacks. This is true to the fact that the attacks are the genuine reaction of the oppressed Islamic minorities that seek to demolish the American hegemony to affirm their own self autonomy. In this regard, the discussion has concentrated on some other issues in relation with islamophobia. They are hegemony and self-other relationship that governs the ideological clash between the American foreign politics and the Islamic extremists. The discussion has explored this clash as the essence of new orientalism.

The theoretical background of the discussion focuses on islamophobia and its contribution to the conceptualization of Islam in the contemporary world. Therefore, the main argument has been on the hegemonic meanings and insights produced by islamophobia. One of these meanings is inferiority. It means that the hegemonic powers encounter two archetypes, namely, the superior and the inferior. The superior practices his power over the inferior. Once the inferior feels this inferiority, a struggle between the superior and the inferior comes out. The result is that the superior imposes hegemonic confines over the inferior. Here, inferiority has nothing to do with the colonial powers.Thus, the analytical discussion of islamophobia has discovered the symbolical metamorphosis of the traditional "Orient's" image into neo orientalism.

\section{REFERENCES}

[1] Abu Jweid, A. (2016). The fall of national identity in Chinua Achebe's Things Fall Apart. PERTANIKA, 23(5), 529 - 540.

[2] Ahmad, A. (1992). In theory: class, nations, literature. London: Verso.

[3] Allen, C. (2010). Islamophobia. Birmingham:Ashgate Publishing Limited.

[4] Aulette, J. R. (2017). A global view of face and racism. New York: Oxford University Press.

[5] Bakali, N. (2016). Islamophobia: Understanding anti-muslim racism through the lived experiences of Muslim youth. Rotterdam: Sense Publishers.

[6] Branche, Jerome. (2015). The poetics and politics of diaspora: Transatlantic musings. New York: Routledge.

[7] Chew, S., and David R. (2014). A concise companion to postcolonial literature. Chichester: Malden, MA WileyBlackwell.

[8] Dawoody, A. (2007). Eradicating terrorism from the Middle East: Policy and administrative approaches. Cham: Springer International Publishing.

[9] DeLillo, D. (2007). Falling man. London: Picador.

[10] Edmond, R., and Vanessa S. (2003). Islands in history and representation. London: Routledge.

[11] Fekete, L. (2009). A suitable enemy: Racism, migration and islamophobia in Europe. London: Pluto.

[12] Hodgkins, C. (2002). Reforming empire: Protestant colonialism and conscience in British literature. Columbia: University of Missouri Press.

[13] Meer, N. (2016). Racialization and religion: Race, culture and difference in the study of antisemitism and islamophobia. London: Routledge.

[14] Newell, S. (2006). West African literatures: Ways of reading. Oxford: Oxford University Press.

[15] Ramberg, I. (2004). Islamophobia and its consequences on young people. Budapest: European Youth Centre Budapest.

[16] Rooney, C. (2007). Disclosing gender: Literature and a poetics of the real. Routledge: New York.

[17] Saeed, T. (2016). Islamophobia and securitization: Religion, ethnicity and the female voice. Cham: Springer International Publishing.

[18] Said, E. (1979). Orientalism. New York: Vintage Books.

[19] Sheffer, G. (1986). Modern diasporas in international politics. London and Sydney: Croom Helm. 
[20] Shryock, A. (2010). Islamophobia/islamophilia: Beyond the politics of enemy and friend. Bloomington: Indiana University Press.

[21] Soharwardy, S. B. (2016). Defeating hate: A comprehensive rebuttal of Taliban, Alqaeda, Daesh (isis) and Islamophobes. Calgary, Alberta: Islamic Supreme Council of Canada: Muslims Against Terrorism.

[22] Tabron, J. (2003). Postcolonial literature from three continents: Tutuola, H.d., Ellison, and White. New York: Peter Lang.

[23] Williams, P., and Laura C. (2015). Colonial discourse and post-colonial theory: A reader. London: Routledge.

[24] Winkler, B. (2006). Muslims in the European Union: Discrimination and islamophobia. Lisbon: EUMC. 